\title{
Efektivitas Pemberian Ekstrak Kipahit (Tithonia diversifolia) sebagai Imunostimulan untuk Pencegahan Motile Aeromonas Septicemia (MAS) pada Ikan Patin (Pangasionodon hypophthalmus)
}

\section{Efficacy of Kipahit Tithonia diversifolia as Immunostimulant Prevention Against Motile Aeromonas Septicemia (MAS) in Catfish Pangasionodon hypophthalmus}

\author{
Edwina Dhyani Danaparamita, Mulyana, dan Angela Mariana Lusiastuti
}

\begin{abstract}
Motile Aeromonas Septicemia is a disease which is commonly found in aquaculture activities, and catfish is one of the commodities that are often exposed by the disease. The aims of this research was to get the best dose of kipahit simplicia to prevent against MAS in catfish. The experiment was carried out on January $10^{\text {th }} 2014$ until $22^{\text {nd }}$ March 2014 in BPPBAT Sempur, Bogor. Catfish mantained for 28 days before bacterial infection and 10 days after bacterial infection with feed treatments containing different doses of kipahit simplicia 2,44\%, 4,76\%,9.09\%, and $16.67 \%$. Commercial feed without addition of simplicia was given as a control. The results showed that treatments after bacterial infection affect to the immune system of catfish but did not showed the bactericidal activity. All the treatments before and after bacterial infection did not affect the Survival Rate (SR), Feed Convertion Ratio (FCR), and Specific Growth Rate (SGR) in catfish.The best dose of kipahit simplicia for prevention against MAS in catfish is $16,67 \%$ because the immunostimulant activity works better compared to the other doses and safe for liver based on the liver function test.
\end{abstract}

Keywords : Catfish, feed, kipahit, Motile Aeromonas Septicemia.

\begin{abstract}
ABSTRAK
Motile Aeromonas Septicemia (MAS) merupakan penyakit yang sering ditemui pada kegiatan budidaya, dan salah satu komoditas yang sering terserang oleh penyakit ini adalah ikan patin. Penelitian ini bertujuan mendapatkan dosis terbaik dari simplisia tanaman kipahit untuk mencegah (MAS) pada ikan patin. Percobaan dilaksanakan tanggal 10 Januari 2014 sampai dengan 22 Maret 2014 bertempat di Balai Penelitian dan Pengembangan Budidaya Air Tawar, Sempur, Bogor. Ikan patin dipelihara selama 28 hari sebelum uji tantang dan 10 hari setelah uji tantang dengan perlakuan pakan menggunakan campuran simplisia kipahit dengan dosis 2,44\%; 4,76\%; 9,09\%; dan $16,67 \%$. Perlakuan kontrol adalah pakan komersil tanpa penambahan simplisia kipahit. Hasil penelitian menunjukkan bahwa pemberian pakan seluruh dosis perlakuan, baik sebelum maupun sesudah uji tantang tidak mempengaruhi nilai tingkat kelangsungan hidup, rasio konversi pakan, dan laju pertumbuhan spesifik ikan patin. Pemberian perlakuan setelah dilakukan uji tantang diduga memberikan pengaruh terhadap respon imun terhadap ikan patin, tetapi tidak memiliki aktivitas bakterisidal. Dosis simplisia kipahit terbaik untuk pencegahan MAS pada ikan patin adalah 16,67\% karena pada dosis tersebut aktivitas imunostimulan bekerja lebih baik dibandingkan dosis yang lainnya, serta aman terhadap organ hati berdasarkan uji fungsi hati.

Kata kunci : Ikan patin, kipahit, Motile Aeromonas Septicemia, pakan.
\end{abstract}

Edwina Dhyani Danaparamita, Mulyana, Angela Mariana Lusiastuti. 2017. Efektivitas Pemberian Ekstrak Kipahit (Tithonia diversifolia) sebagai Imunostimulan untuk Pencegahan Motile Aeromonas Septicemia (MAS) pada Ikan Patin (Pangasionodon hypophthalmus). Jurnal Mina Sains 3(1):19-29. 


\section{PENDAHULUAN}

\section{Latar Belakang}

Berdasarkan data Dinas Kelautan dan Perikanan tahun 2006, permintaan konsumen untuk ikan air tawar semakin meningkat, hal ini membuat para pelaku budidaya meningkatkan kegiatan produksinya (Sakti 2013). Ikan patin (Pangasionodon hypophthalmus) merupakan salah satu jenis ikan yang banyak dibudidayakan di Indonesia. Ikan ini memiliki nilai ekonomis yang cukup tinggi dan serta mengalami perkembangan produksi yang meningkat secara signifikan. Pada tahun 2006 produksi ikan patin mencapai 31.490 ton (Sakti 2013) dan pada tahun 2013 mengalami peningkatan menjadi 61.215 ton (Noegroho 2014). Pemerintah menargetkan produksi nasional ikan patin sebesar 117.840 ton pada tahun 2014 (Noegroho 2014), dengan kata lain meningka dua kali lipat dibandingkan tahun sebelumnya. Ikan patin sendiri merupakan komoditas budidaya air tawar dengan kenaikan produksi paling tinggi dibandingkan dengan komoditas lainnya (Sakti 2013). Produksi ikan patin tidak hanya untuk memenuhi kebutuhan dalam negeri, tetapi juga untuk memenuhi permintaan ekspor.

Kenaikan target produksi ikan patin sebesar $70 \%$ dibandingkan tahun sebelumnya menyebabkan perlu dilakukannya budidaya ikan patin secara intensif. Sistem budidaya intensif ini tidak terlepas dari munculnya penyakit yang dapat disebabkan oleh bakteri, virus, atau parasit. Salah satu bakteri yang sering menyerang ikan patin adalah spesies Aeromonas hydrophila yang menyebabkan Motile Aeromonas Septicemia (MAS). Penyakit MAS ini timbul akibat rendahnya ketahanan tubuh ikan dalam menghadapi serangan bakterial, lingkungan pemeliharaan yang buruk dan manajemen pemberian pakan yang kurang baik. Ikan yang terserang akan mengalami pendarahan pada bagian tubuh terutama dada, perut, dan pangkal sirip (Wahjuningrum et al. 2008). Ikan patin yang terpapar bakteri mudah menular sehingga harus segera dimusnahkan, sedangkan yang masih mengalami infeksi ringan dapat dicoba dengan beberapa cara pengobatan.

Cara pengobatan yang umum dilakukan untuk mengobati ikan yang terpapar MAS adalah dengan menggunakan antibiotik, seperti nitrofuran dan senyawa kimia seperti kalium permanganat (Wahjuningrum et al. 2008). Akan tetapi penggunaan antibiotik secara terus-menerus dapat menyebabkan beberapa kerugian, diantaranya adalah meningkatnya resistensi bakteri serta menimbulkan residu yang berbahaya pada produk akuakultur dan lingkungan (Direkbusarkom et al. 1998). Alternatif yang dapat dilakukan adalah pengobatan menggunakan bahan herbal yang berasal dari tumbuhan (fitofarmaka).

Pada penelitian terdahulu Widyastuti (2012) telah menguji delapan belas jenis tanaman untuk uji in vitro terhadap bakteri Streptococcus agalactiae dan Aeromonas hydrophila, dan salah satunya dengan menggunakan tanaman kipahit (Tithonia diversifolia). (Odayemi et al. 2014).

Pada penelitian yang akan dilakukan ini, tanaman tersebut diujikan untuk pencegahan $A$. hydrophila pada ikan patin secara in vivo sehingga diharapkan didapat dosis terbaik untuk pencegahan terhadap MAS pada ikan patin.

\section{Tujuan}

Tujuan dilakukannya penelitian ini adalah untuk mendapatkan dosis terbaik dari tanaman kipahit sebagai imunostimulan untuk mencegah Motile Aeromonas Septicemia (MAS) pada ikan patin.

Hipotesis

Simplisia tanaman kipahit yang diberikan melalui pakan dapat berfungsi sebagai imunostimulan untuk mencegah Motile Aeromonas Septicemia (MAS) pada ikan patin.

\section{BAHAN DAN METODE}

\section{Waktu dan Tempat}

Penelitian dilakukan pada tanggal 10 Januari 2014 hingga 22 Maret 2014, bertempat di Balai Penelitian dan Pengembangan Budidaya Air Tawar (BPPBAT), yang beralamat di Jalan Sempur nomor 1, Bogor. Pengecekan darah secara klinis dilakukan di Laboratorium Mandapa, Jalan Raya Pajajaran nomor 14, Baranangsiang, Bogor.

\section{Alat dan Bahan}

Ikan yang digunakan adalah ikan patin (Pangasionodon hypophtalmus). Ikan dibeli dari Bejo Farm di daerah Kemang, Kabupaten Bogor, sebanyak 1100 ekor dengan ukuran tubuh berkisar antara 3-4 inchi. Sampling 
dilakukan setiap minggu (bobot, panjang total, panjang baku) untuk menentukan feeding rate. Ikan yang digunakan sebanyak 30 ekor per akuarium.

Pemeliharaan ikan dilakukan dalam akuarium plastik berbentuk persegi empat dengan ukuran $45 \times 30 \times 35 \mathrm{~cm}^{3}$ dan diisi air kurang lebih $25 \mathrm{~cm}$. Akuarium yang digunakan berjumlah 15 buah yang dirangkai membentuk sistem resirkulasi pada setiap perlakuannya.

Pakan yang digunakan adalah pakan komersil dengan komposisi $40 \%$ protein dengan bobot $1 \mathrm{~kg}$ untuk setiap perlakuan. Pakan komersil dicampur dengan simplisia kipahit (Tithonia diversifolia) dengan dosis simplisia kipahit $25 \mathrm{~g} / \mathrm{kg}$ pakan $(2,44 \%), 50$ $\mathrm{g} / \mathrm{kg}$ pakan (4,76\%), $100 \mathrm{~g} / \mathrm{kg}$ pakan $(9,09 \%)$, dan $200 \mathrm{~g} / \mathrm{kg}$ pakan $(16,67 \%)$. Binder yang digunakan adalah tapioka $5 \mathrm{~g} / \mathrm{kg}$ pakan yang dicampurkan dan dibentuk pellet (repelleting) dengan diameter $3 \mathrm{~mm}$. Pellet dikeringkan dalam oven selama 1 hari hingga kadar air dalam pakan kurang lebih 10\%. Pakan yang telah jadi dibungkus menggunakan plastik dan disimpan dalam refrigerator. Untuk pakan kontrol disiapkan dengan cara yang sama tanpa pencampuran dengan simplisia tanaman. Pemberian pakan tiga kali sehari pada jam 09.00, 12.00, dan 16.00 WIB dengan jumlah yang telah ditentukan. Feeding rate diberikan $5 \%$ dari bobot tubuh. Jumlah pakan yang diberikan perhari dapat berubah sesuai biomassa ikan. Pakan diberikan selama 28 hari selama perlakuan sebelum uji tantang dan 10 hari setelah perlakuan uji tantang.

Tanaman diperoleh dari Balai Penelitian Tanaman Rempah dan Obat (BALITRO) Bogor. Tanaman dicuci bersih dengan air dan dilap dengan kertas/tissue. Kemudian tanaman diiris tipis agar mudah dikeringkan. Tanaman dimasukkan ke dalam oven $50^{\circ} \mathrm{C}$ semalam sampai tanaman mudah dihancurkan dengan tangan. Setelah itu, tanaman digiling dengan mesin penggiling hingga partikelnya berukuran $425 \mu \mathrm{m}$ (amplitudo 1,5 $\mathrm{mm} /$ detik selama 2 menit). Bubuk tanaman disimpan dalam wadah dan disimpan dalam lemari pendingin.

\section{Penyediaan Bakteri}

Bakteri yang digunakan dalam penelitian ini adalah $A$. hydrophila strain M3 yang merupakan koleksi Laboratorium
Patologi BPPBAT Sempur, Bogor. Sebelum digunakan dilakukan pewarnaan Gram serta pengujian biokimia yang meliputi uji oksidase, katalase, motilitas, cephalotin, 0/129 vibriostatik, dan Triple Sugar Iron Agar (TSIA) terlebih dahulu. Bakteri A. hydrophila kemudian dikultur menggunakan media Tryptone Soya Agar (TSA) dan Tryptone Soya Broth (TSB).

\section{Rancangan Penelitian}

Rancangan yang digunakan dalam penelitian ini adalah Rancangan Acak Lengkap (RAL) dengan 5 perlakuan dan 3 ulangan untuk masing-masing dosis. Perlakuan tersebut, yaitu:

1. $16,67 \%$ kipahit dalam pakan

2. $9,09 \%$ kipahit dalam pakan

3. $4,76 \%$ kipahit dalam pakan

4. $2,44 \%$ kipahit dalam pakan

5. Pakan komersil (kontrol).

Model matematika rancangan acak lengkap tersebut adalah:

Keterangan:

$$
\mathrm{Y} i j=\mu+\mathrm{A} i+\varepsilon i j
$$

Y $i j=$ nilai pengamatan

$\mu=$ nilai rata-rata umum

$\mathrm{Ai}=$ pengaruh taraf perlakuan ke- $\mathrm{i}$ $(\mathrm{i}=1,2,3,4,5)$

$\mathrm{E} i j=$ galat percobaan $(\mathrm{i}=1,2,3,4,5$; $\mathrm{j}=1,2,3$ )

\section{Parameter Pengamatan}

\section{Uji Analisis Darah}

Uji analisa darah meliputi uji Nitroblue Tetrazolium (NBT), uji lisozim, dan uji aktivitas bakterisidal. Pengambilan darah dilakukan pada hari ke-0, 15, dan 30. Saat hari ke-0, sebelum ikan dimasukkan ke dalam akuarium percobaan, ikan diambil secara acak sebanyak tiga ekor dari setiap perlakuan untuk diambil darahnya. Setelah itu, darah diletakkan pada satu eppendorf yang berisi heparin (antikoagulan) atau Na-sitrat untuk diuji NBT dan eppendorf lain yang tidak diberi antikoagulan untuk uji lisozim dan aktivitas bakterisidal.

\section{Uji BNT}

Uji NBT dilakukan dengan tujuan untuk mengetahui kemampuan neutrofil untuk mereduksi larutan NBT melalui pembentukan oksigen radikal (Stasiak dan Baumann 1996). Pengujian ini dilakukan dengan cara sebagai 
berikut; darah yang terdapat di dalam eppendorf berisi heparin dimasukkan ke dalam well sebanyak $50 \mu \mathrm{L}$. ulangan dilakukan 3 kali untuk setiap sampel. Setelah itu, well bagian atas ditutup dengan aluminium foil dan diinkubasi pada suhu $37^{\circ} \mathrm{C}$ selama 1 jam. Kemudian well yang berisi darah dibilas dengan Phosphate Buffer Saline (PBS) $100 \mu \mathrm{L}$ sebanyak 3 kali. Setelah dibilas, NBT 0,2\% ditambahkan sebanyak $50 \mu \mathrm{L}$ dan diinkubasi pada suhu ruang selama 1 jam. Setelah itu, difiksasi dengan larutan methanol $100 \%$ sebanyak $50 \mu \mathrm{L}$ selama 2-3 menit dan dibilas sebanyak 3 kali dengan larutan methanol 30\% sebanyak $50 \mu \mathrm{L}$. Kemudian dikering anginkan dan ditambahkan $60 \mu \mathrm{L}$ potassium hydroxide serta $70 \mu \mathrm{L}$ dimethyl sulphoxide pada masingmasing sumur yang berisi sampel. Selanjutnya dilakukan pembacaan dengan Enzym-linked Immunosorbent Assay (ELISA) reader dengan panjang gelombang $540 \mathrm{~nm}$.

\section{Uji Lisozim}

Darah yang terdapat pada eppendorf tanpa heparin disentrifuse dengan kecepatan 3000 rpm selama 10 menit. Setelah itu, serum diambil dan dipindahkan ke eppendorf yang baru. Serum sebanyak $100 \mu \mathrm{L}$ ditambahkan Micrococcus lysodeikticus $1900 \mu \mathrm{L}$ yang diencerkan dengan $0,2 \mathrm{mg} / \mathrm{L} 0,05 \mathrm{M} \mathrm{NaH}_{2} \mathrm{PO}_{4}$ pada suhu $25^{\circ} \mathrm{C}$. Kemudian dilakukan pembacaan dengan spektrofotometer menggunakan panjang gelombang $540 \mathrm{~nm}$ setelah 30 detik dan 4,5 menit.

\section{Aktivitas Bakterisidal}

Pengujian Bakterisidal bertujuan untuk mengukur kemampuan antibodi yang terdapat pada serum atau plasma untuk membunuh bakteri (WHO 1999). Serum sebanyak $100 \mu \mathrm{L}$ dicampur dengan suspensi bakteri (Aeromonas hydrophila $10^{4} \mathrm{cfu} / \mathrm{mL}$ ) dan diinkubasi pada suhu $32^{\circ} \mathrm{C}$ selama 1 jam. Kontrol disiapkan juga dengan cara mengganti serum darah dengan larutan PBS steril. Setelah diinkubasi, larutan diencerkan dengan PBS steril dengan perbandingan 1:10. Sebanyak $100 \mu \mathrm{L}$ dari larutan disebar ke cawan agar dan diinkubasi pada suhu $32^{\circ} \mathrm{C}$ selama 24 jam. Koloni akan tumbuh pada media agar tersebut dan dihitung dengan rumus:

$$
\% \text { Killing }=\frac{1-\mathrm{cfu} \text { tanpa serum }}{\mathrm{cfu} \text { dengan serum }} \times 100
$$

\section{Uji Toksikologi}

Pengujian darah di klinik dilakukan dengan tujuan untuk mengetahui efek toksisitas herbal yang digunakan. Sebelum dilakukan uji tantang, diambil darah sebanyak $1 \mu \mathrm{l}$ dan dimasukkan ke dalam eppendorf yang telah diisi dengan antikoagulan. Sampel selanjutnya dibawa ke laboratorium untuk dilakukan pengecekan terhadap bebrapa parameter meliputi Serum Glutamic-Piruvic Transaminase (SGPT), Serum GlutamicOxaloacetic Transaminase (SGOT), alkalin fosfat, protein, albulin, dan imunoglobulin. Darah diambil dari 6 ekor ikan yang berasal dari perlakuan dengan dosis tertinggi (200 gram), dosis sedang (50 gram), serta kontrol.

\section{Tingkat Kelangsungan Hidup}

Data kelangsungan hidup didapatkan melalui pengamatan harian. Ikan yang hidup pada akhir pemeliharaan (Nt) dihitung dan jumlah ikan pada awal tebar (No) dicatat. Menurut Effendie (1979), tingkat kelangsungan hidup dihitung dengan rumus:

$$
S R=\frac{N t}{N 0} x 100 \%
$$

Keterangan:

$\mathrm{SR}=$ tingkat kelangsungan hidup $(\%)$

$\mathrm{Nt}=$ jumlah individu pada akhir perlakuan (ekor)

$\mathrm{N} 0=$ jumlah individu pada awal perlakuan (ekor)

\section{Laju Pertumbuhan Spesifik}

Laju pertumbuhan spesifik (Specific Growth Rate) ikan dilakukan sebelum dan setelah uji tantang. Menurut Effendie (1979) SGR dapat dihitung dengan menggunakan rumus :

$$
S G R=\left(\sqrt[t]{\frac{W t}{W o}}-1\right) \times 100 \%
$$

Keterangan:

SGR $=$ Laju pertumbuhan spesifik $(\% /$ hari $)$

$\mathrm{W}_{\mathrm{t}}=$ Bobot rata-rata pada akhir perlakuan (gram)

$\mathrm{W}_{0}=$ Bobot rata-rata pada awal perlakuan (gram)

$\mathrm{t}=$ Lama pemeliharaan (hari) 


\section{Tingkat Konversi Pakan}

Tingkat konversi pakan dihitung dari persentase dengan jumlah pakan yang diberikan dibagi jumlah biomassa ikan yang dihasilkan. Menurut Effendie (1979) tingkat konversi pakan dihitung menggunakan rumus:

$$
F C R=\frac{F}{B t-B o+B d}
$$

Keterangan:

$$
\begin{aligned}
& \mathrm{FCR}=\text { Tingkat Konversi Pakan } \\
& \mathrm{Bd}=\text { Bobot ikan mati }(\text { gram) } \\
& \mathrm{Bt}=\text { Bobot ikan akhir (gram) } \\
& \mathrm{F}=\text { Jumlah pakan (gram) } \\
& \mathrm{Bo}=\text { Bobot ikan awal (gram) }
\end{aligned}
$$

\section{Analisis Data}

Data yang dihasilkan diolah dengan menggunakan software SPSS 18.0, selanjutnya dianalisis secara statistik dengan Uji Duncan pada selang kepercayaan 95\%. Data uji respiratory burst activity, lisozim, bakterisidal, tingkat kelangsungan hidup, laju pertumbuhan spesifik, dan tingkat konversi pakan diolah secara statistik. Data uji toksikologi dan analisis kualitas air diolah secara deskriptif.

\section{HASIL DAN PEMBAHASAN}

Hasil

\section{Respiratory Burst Activity}

Respiratory Burst Activity atau letupan respiratorik sebagai salah satu parameter pengujian imunologi, menunjukkan hasil seperti yang ditampilkan pada Gambar 1. Kontrol merupakan hasil pengujian sebelum ikan diberi perlakuan pakan yang dicampur dengan simplisia kipahit.

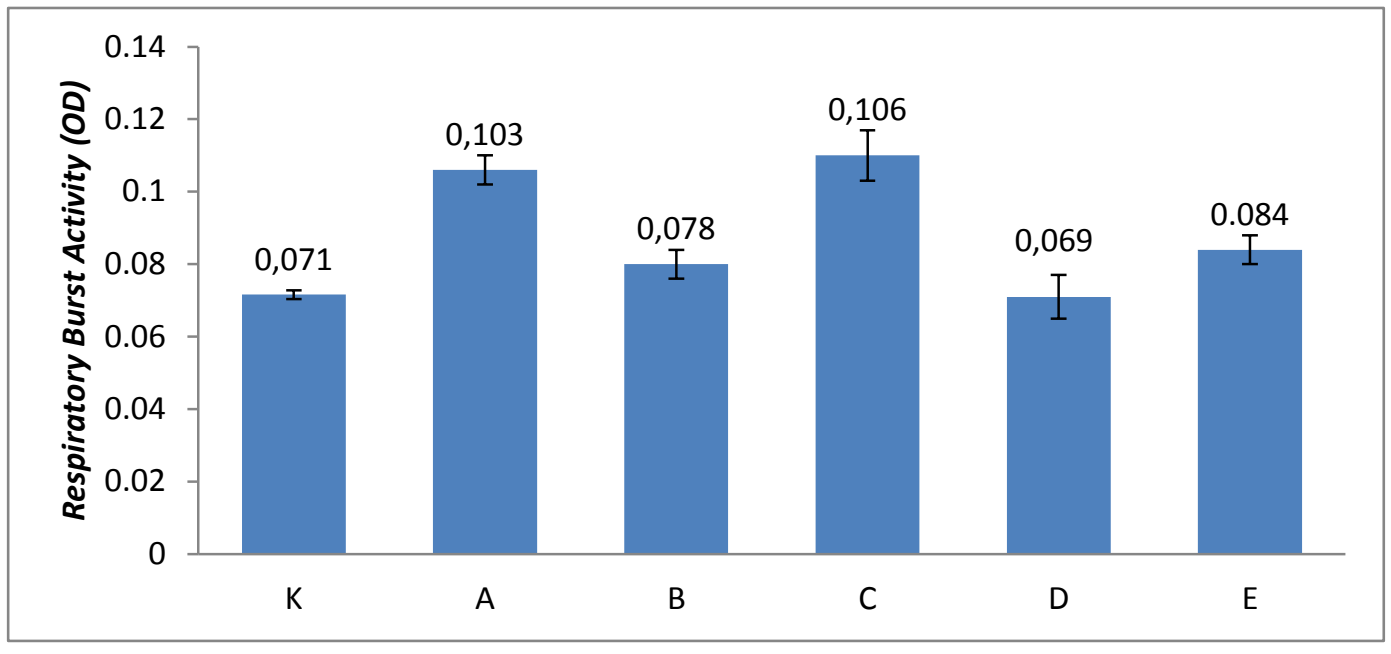

Gambar 1 Respiratory burst activity ikan patin dengan pemberian pakan berbagai dosis simplisia kipahit

Keterangan : $\mathrm{A}=$ dosis $16,67 \%, \mathrm{~B}=9,09 \%, \mathrm{C}=$ dosis $4,76 \%, \mathrm{D}=$ dosis $2,44 \%$, $\mathrm{E}=$ tanpa tambahan simplisia kipahit , $\mathrm{K}=$ kontrol

\section{Uji Lisozim}

Lisozim merupakan salah satu parameter pengujian imunologi, menunjukkan hasil seperti yang tertera pada Gambar 2. Kontrol merupakan hasil pengujian sebelum ikan diberi perlakuan pakan yang dicampur dengan simplisia.

\section{Aktivitas Bakterisidal}

Aktivitas bakterisidal merupakan salah satu parameter uji imunologi ikan patin, hasil ditampilkan dalam Gambar 3. 


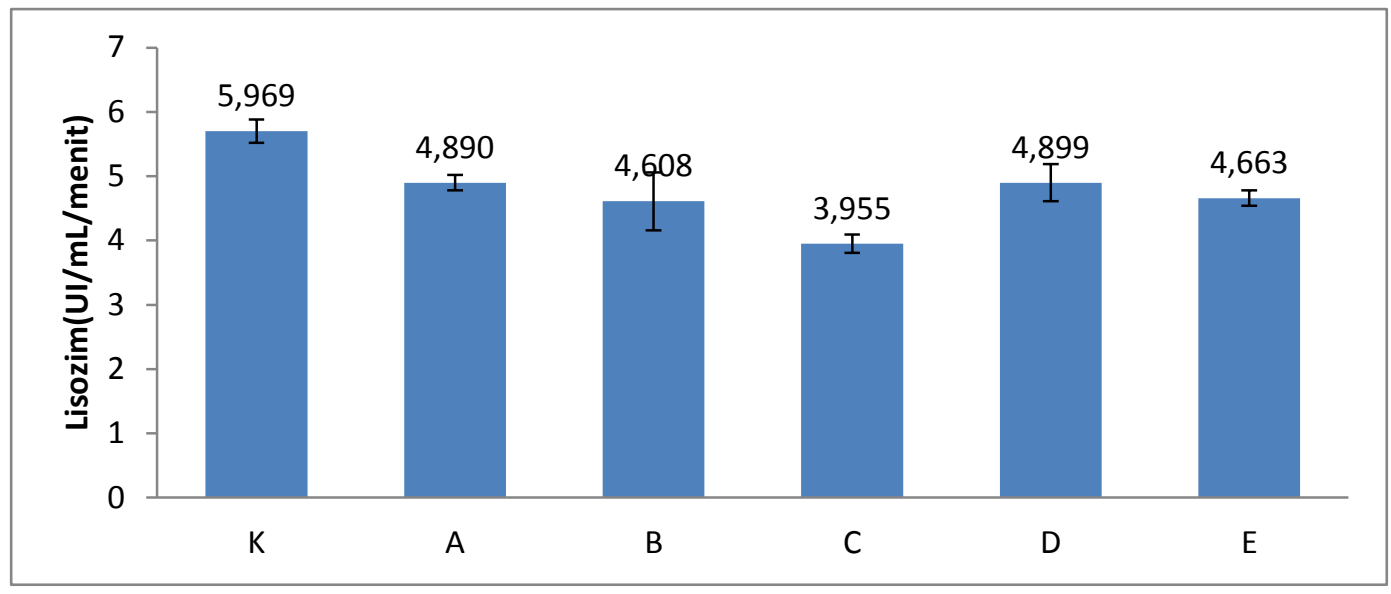

Gambar 2 Nilai aktivitas lisozim ikan patin dengan pemberian pakan berbagai dosis simplisia kipahit

Keterangan : $\mathrm{A}=$ dosis $16,67 \%, \mathrm{~B}=9,09 \%, \mathrm{C}=$ dosis $4,76 \%, \mathrm{D}=\operatorname{dosis} 2,44 \%$, $\mathrm{E}=$ tanpa tambahan simplisia kipahit, $\mathrm{K}=$ kontrol

Tingkat Kelangsungan Hidup / Survival selama 28 hari pemeliharaan sebelum uji Rate (SR) tantang dan 10 hari pemeliharaan setelah uji

Data kelangsungan hidup ikan patin tantang (Gambar 4). (Pangasionodon hypophthalmus) diamati

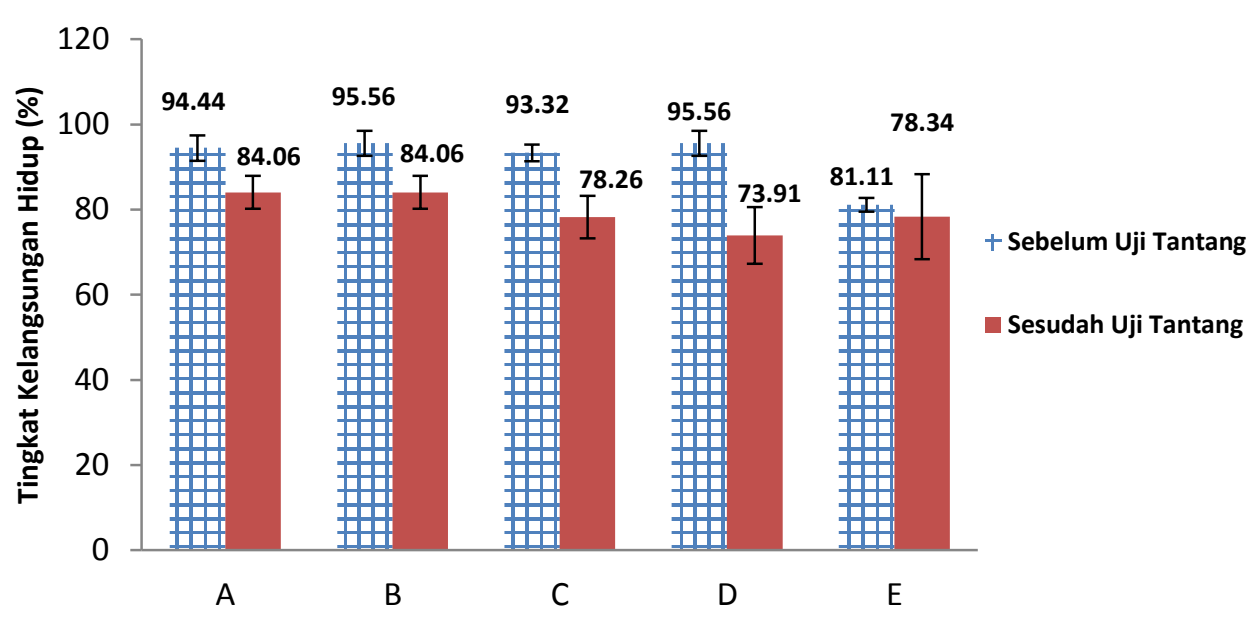

Gambar 4 Tingkat kelangsungan hidup ikan patin dengan pemberian pakan berbagai dosis simplisia kipahit sebelum dan sesudah diuji-tantang dengan Aeromonas hydrophila

Keterangan : $\mathrm{A}=$ dosis $16,67 \%, \mathrm{~B}=9,09 \%, \mathrm{C}=$ dosis $4,76 \%, \mathrm{D}=$ dosis $2,44 \%, \mathrm{E}=$ tanpa tambahan simplisia kipahit

Tingkat Konversi Pakan / Feed Convertion Ratio (FCR)

Nilai tingkat konversi pakan (FCR) didapatkan dari pengamatan setelah sampling yang dilakukan selama pemeliharaan 28 hari sebelum uji tantang sehingga didapatkan nilai FCR setiap perlakuan seperti yang tertera pada Gambar 5. 


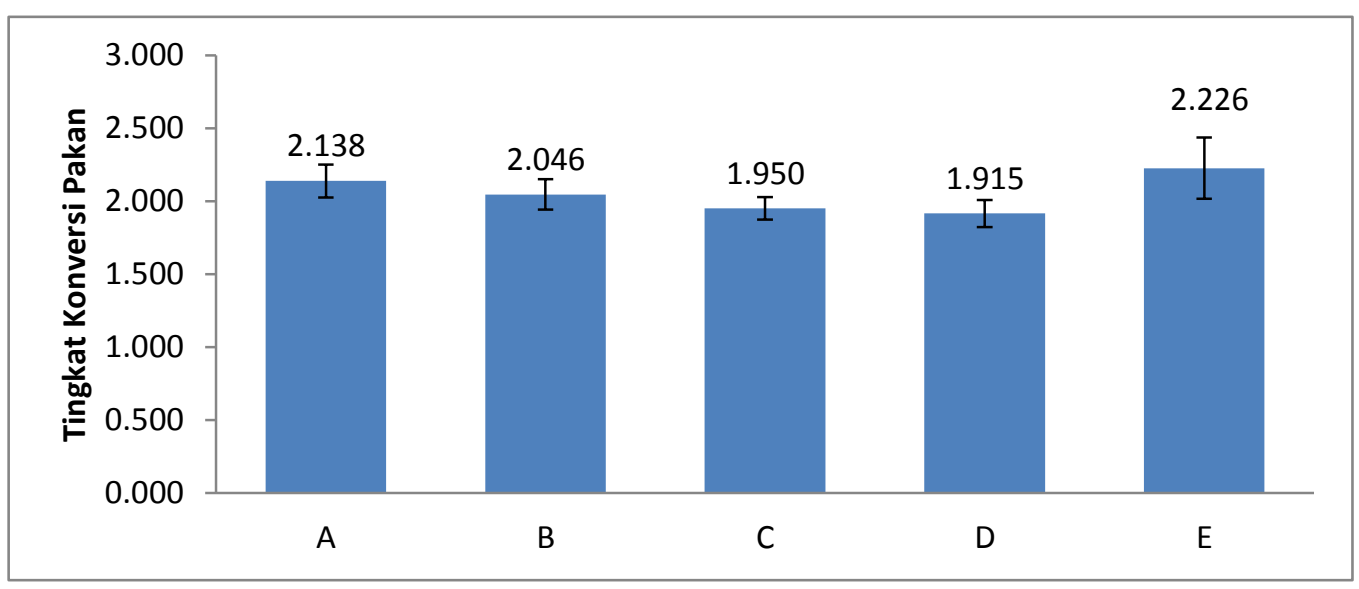

Gambar 5 Tingkat konversi pakan (FCR) ikan patin dengan pemberian pakan berbagai dosis simplisia kipahit selama pemeliharaan 28 hari

Keterangan : $\mathrm{A}=$ dosis $16,67 \%, \mathrm{~B}=9,09 \%, \mathrm{C}=$ dosis $4,76 \%, \mathrm{D}=$ dosis $2,44 \%, \mathrm{E}=$ tanpa tambahan simplisia kipahit

Laju Pertumbuhan Spesifik/Specific Growth Rate (SGR)

Pengaruh pemberian dosis yang

pertumbuhan spesifik ikan uji digambarkan pada Gambar 6.

berbeda pada setiap perlakuan dengan laju

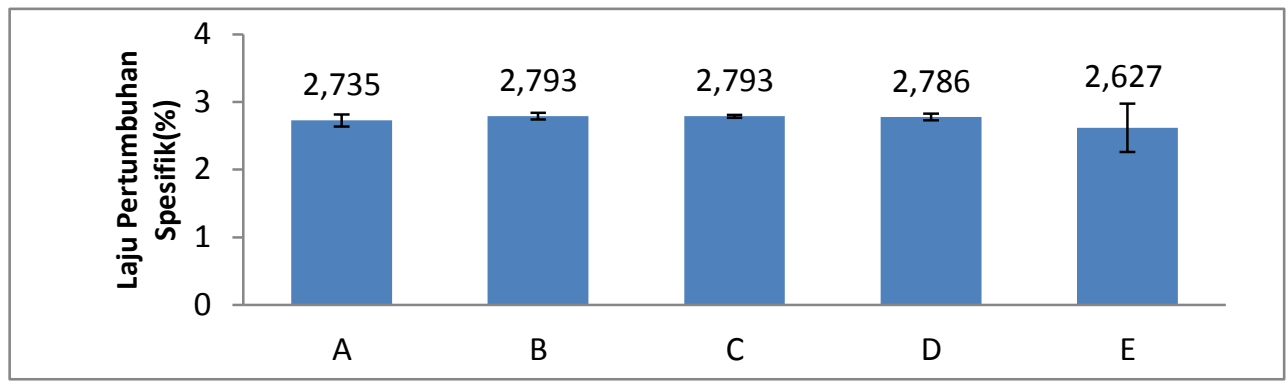

Gambar 6 Laju pertumbuhan spesifik (SGR) ikan patin dengan pemberian pakan berbagai dosis simplisia kipahit

Keterangan : $\mathrm{A}=$ dosis $16,67 \%, \mathrm{~B}=9,09 \%, \mathrm{C}=$ dosis $4,76 \%, \mathrm{D}=$ dosis $2,44 \%, \mathrm{E}=$ tanpa tambahan simplisia kipahit

\section{Uji Toksikologi}

Uji toksikologi dilakukan setelah perlakuan pemberian pakan yang dicampurkan dengan simplisia kipahit. Hasil pengujian meliputi beberapa parameter yaitu SGPT, SGOT, alkalin fosfat, total protein, albumin, dan globulin yang hasilnya disajikan dalam Tabel 1.

Tabel 1. Parameter fungsi hati terhadap uji toksikologi

\begin{tabular}{|c|c|c|c|c|c|c|}
\hline Treatment & $\begin{array}{l}\text { SGPT } \\
\text { (unit } / \mu \mathrm{L} \text { ) }\end{array}$ & $\begin{array}{l}\text { SGOT } \\
\text { (unit/ } / \mu \mathrm{L} \text { ) }\end{array}$ & $\begin{array}{l}\text { Alkalin } \\
\text { Fosfat } \\
\text { (unit/pL) }\end{array}$ & $\begin{array}{l}\text { Protein } \\
(\mathrm{gram} / \mu \mathrm{L})\end{array}$ & $\begin{array}{l}\text { Albumin } \\
(\mathrm{gram} / \mu \mathrm{L})\end{array}$ & $\begin{array}{l}\text { Globulin } \\
\text { (gram } / \mu \mathrm{L})\end{array}$ \\
\hline A & 19,50 & 299,17 & 48,00 & 3,15 & 1,27 & 1,88 \\
\hline $\mathrm{C}$ & 24,00 & 306,17 & 60,50 & 3,31 & 1,27 & 2,04 \\
\hline $\mathrm{E}$ & 29,83 & 307,17 & 51,83 & 3,47 & 1,31 & 2,16 \\
\hline
\end{tabular}

Keterangan : $\mathrm{A}=$ dosis $16,67 \%, \mathrm{C}=\mathrm{dosis} 4,76 \%, \mathrm{E}=\tan$ a penambahan simplisia kipahit 


\section{Uji Kualitas Air}

Pengujian kualitas parameter kualitas air (suhu, $\mathrm{pH}$, dan DO) dilakukan setiap pagi hari. Parameter nitrat, nitrit, dan TAN diukur Tabel 2. Kualitas air pada $\mathrm{H}_{0}$ (sebelum masa perlakuan) dan $\mathrm{H}_{30}$ (akhir masa perlakuan). Hasil uji kualitas air ditampilkan pada Tabel 2.

\begin{tabular}{|c|c|c|c|c|c|c|c|c|c|}
\hline \multirow[t]{3}{*}{ Perlakuan } & \multicolumn{9}{|c|}{ Parameter } \\
\hline & \multirow{2}{*}{$\begin{array}{c}\text { Suhu } \\
\left({ }^{0} \mathrm{C}\right)\end{array}$} & \multirow[t]{2}{*}{$\mathrm{pH}$} & \multirow{2}{*}{$\begin{array}{c}\text { DO } \\
(\mathrm{ppm})\end{array}$} & \multicolumn{2}{|c|}{ Nitrit(ppm) } & \multicolumn{2}{|c|}{ Nitrat(ppm) } & \multicolumn{2}{|c|}{ TAN(ppm) } \\
\hline & & & & $\mathrm{H} 0$ & $\mathrm{H} 30$ & $\mathrm{H} 0$ & $\mathrm{H} 30$ & $\mathrm{H} 0$ & $\mathrm{H} 30$ \\
\hline $16,67 \%$ & $28,20-31,20$ & $7,32-8,50$ & $5,91-6,45$ & 1,88 & 2,42 & 0,54 & 0,85 & 0,27 & 1,46 \\
\hline $9,09 \%$ & $28,00-33,42$ & $7,40-8,66$ & $5,84-6,60$ & 1,72 & 2,38 & 0,39 & 0,77 & 0,19 & 1,21 \\
\hline $4,76 \%$ & $28,85-32,20$ & $7,61-8,70$ & $5,82-6,16$ & 1,69 & 2,21 & 0,43 & 0,82 & 0,13 & 1,36 \\
\hline $2,44 \%$ & $29,00-30,31$ & $7,50-8,70$ & $5,20-6,42$ & 1,33 & 2,19 & 0,32 & 0,71 & 0,10 & 1,22 \\
\hline Kontrol & $27,10-30,90$ & $6,91-8,74$ & $5,93-7,94$ & 1,18 & 1,58 & 0,29 & 0,62 & 0,12 & 1,29 \\
\hline
\end{tabular}

\section{Pembahasan}

Bahan-bahan alami yang berasal dari tumbuhan dan berfungsi sebagai obat (fitofarmaka) semakin banyak dipergunakan dalam sektor perikanan, baik dalam skala laboratorium maupun dalam skala industri. Penggunaan fitofarmaka untuk pengobatan ikan dipilih dengan pertimbangan untuk mengurangi dampak negatif yang ditimbulkan oleh penggunaan antibiotik berlebih sebagai obat dalam lingkungan budidaya, diantaranya adalah dapat meningkatkan resistensi bakteri serta meninggalkan residu yang berbahaya bagi produk akuakultur beserta lingkungannya (Direkbusarkom et al. 1998). Salah satu jenis fitofarmaka yang dapat dimanfaatkan untuk pencegahan penyakit yang disebabkan oleh bakteri dalam lingkungan budidaya adalah tanaman kipahit. Kandungan zat aktif yang terdapat dalam daun kipahit diantaranya adalah alkaloid, fenol, flavonoid, sesquiterpen (Odayemi et al. 2014), tanin dan saponin (John-Dewole dan Oni 2013) yang berfungsi sebagai agen antimikroba.

Respiratory burst activity atau letupan respiratotik merupakan reaksi terhadap terjadinya infeksi yang merupakan efek sitotoksis pada makrofag. Pengujian respiratory burst activity bertujuan untuk mengetahui kemampuan neutrofil mereduksi larutan nitroblue tetrazolium (NBT) melalui pembentukan oksigen radikal (Stasiak dan Baumann 1996). Pengujian ini memberikan hasil bahwa pemberian simplisia kipahit dosis A $(0,103$ OD) dan C (0,106 OD) memberikan hasil yang berbeda nyata $(\mathrm{P}<0,05)$ dari kontrol.
Hal ini dikarenakan oleh kandungan flavonoid dan tanin yang terdapat dalam daun kipahit. Flavonoid dan tanin yang merupakan golongan polifenol dapat merusak total membran protoplasma (Suherman 2013) dengan mekanisme melisis dinding sel dan menghentikan sintesis protein serta sintesis DNA bakteri (Citarasu 2010). Mekanisme inilah yang kemungkinan menghambat aktivitas bakteri sehingga neutrofil dapat aktif merespon larutan NBT. Hasil perlakuan kontrol didapatkan sebelum ikan diberi perlakuan pakan menggunakan simplisia kipahit, sedangkan perlakuan B (0,07 OD), D (0,06 OD), dan E (0,08 OD) tidak berbeda nyata $(\mathrm{P}>0,05)$ dengan kontrol $(0,07)$. Perlakuan menggunakan ketiga dosis tersebut tidak memberikan efek positif pada respiratory burst activity karena kandungan flavonoid dan tanin kurang berperan dalam mekanisme pertahanan terhadap bakteri, sehingga dosis terbaik kipahit yang dapat digunakan adalah $16,67 \%$. Kandungan lainnya yang tedapat dalam kipahit adalah sesquiterpen yang merupakan senyawa turunan dari terpenoid serta alkaloid (Ambrosio et al. 2008), menurut Wagner (1984) alkaloid dan diterpenoid memiliki kemampuan sebagai imunostimulan.

Aktivitas lisozim merupakan salah satu indikator respon imun non-spesifik. Berdasarkan uji aktivitas lisozim ikan patin didapatkan hasil perlakuan A $(4,89$ $\mathrm{UI} / \mathrm{mL} / \mathrm{menit}), \mathrm{B}(4,61 \mathrm{UI} / \mathrm{mL} / \mathrm{menit}), \mathrm{C}(3,95$ $\mathrm{UI} / \mathrm{mL} / \mathrm{menit}), \mathrm{D}(4,90 \mathrm{UI} / \mathrm{mL} / \mathrm{menit})$, dan $\mathrm{E}$ $(4,66 \mathrm{UI} / \mathrm{mL} / \mathrm{menit})$ berbeda nyata $(\mathrm{P}<0,05)$ dengan kontrol (5,96 UI/mL/menit). 
Menurunnya aktivitas lisozim setelah pemberian perlakuan menggunakan simplisia kipahit kemungkinan disebabkan oleh keadaan fisiologi ikan yang mengalami stress setelah perlakuan. Menurunnya nilai aktivitas lisozim dipengaruhi oleh beberapa hal, salah satunya adalah kondisi fisiologis ikan (Saurabh dan Sahoo 2008).

Parameter lain penentu aktivitas immunologi adalah aktivitas bakterisidal. Uji bakterisidal memberikan hasil perlakuan A $(0,76 \%), \mathrm{B}(0,84 \%), \mathrm{C}(0,84 \%)$, dan D $(0,78 \%)$ tidak berbeda nyata $(\mathrm{P}>0,05)$ dengan kontrol $(0,75 \%)$. Seluruh dosis simplisia kipahit yang dicampurkan dalam pakan tidak memberikan pengaruh terhadap aktivitas bakterisidal. Hal ini mengindikasikan bahwa simplisia kipahit tidak memiliki kemampuan aktivitas bakterisidal. Kemampuan bakterisidal berkaitan dengan aktivitas lisozim, menurut Saurabh dan Sahoo (2008) lisozim pada ikan memiliki kemampuan untuk meningkatkan aktivitas bakterisidal yang terdapat pada organisme tersebut. Rendahnya aktivitas lisozim yang terjadi pada ikan patin setelah diberi perlakuan pakan menggunakan campuran berbagai dosis simplisia kipahit mengakibatkan tidak terjadinya aktivitas bakterisidal.

Berdasarkan hasil uji toksikologi terhadap organ hati ikan patin dengan melihat nilai Serum Glutamic-Piruvic Transaminase (SGPT), Serum Glutamic-Oxaloacetic Tranaminase (SGOT), alkalin fosfat, protein, albumin, dan imunoglobulin diketahui bahwa kipahit tidak memberikan efek terhadap kerusakan hati ikan patin. Pemberian kipahit untuk pencegahan Motile Aeromonas Septicemia (MAS) terbukti aman bagi organ internal ikan patin, dengan dosis tidak lebih dari $16,67 \%$.

Tingkat kelangsungan hidup ikan patin yang dipelihara dengan perlakuan berbagai dosis simplisia kipahit dalam pakan sebelum dilakukan uji tantang (masa pemeliharaan 28 hari) menunjukkan hasil yang tidak berbeda nyata. Perlakuan A $(94,44 \%)$, B $(95,57 \%), C$ $(93,32 \%)$, dan D $(95,57 \%)$ tidak memperlihatkan hasil yang berbeda nyata $(\mathrm{P}>0,05)$ dengan kontrol $(81,11 \%)$. Setelah dilakukan uji tantang (masa pemeliharaan 10 hari) nilai tingkat kelangsungan hidup cenderung menurun jika dibandingkan dengan sebelum dilakukan uji tantang. Tingkat kelangsungan hidup perlakuan A $(84,065 \%)$, B $(84,06 \%), C(78,26 \%)$, dan D $(73,91 \%)$ tidak berbeda nyata $(\mathrm{P}>0,05)$ dengan kontrol $(78,34 \%)$. Hal ini menunjukkan bahwa pemberian simplisia kipahit yang dicampurkan pada pakan tidak memberikan pengaruh terhadap tingkat kelangsungan hidup ikan patin selama masa pemeliharaan, baik sebelum atau setelah dilakukan uji tantang.

Konversi pakan ikan patin diamati selama 28 hari pemeliharaan sebelum dilakukannya uji tantang. Besar kecilnya nilai konversi pakan menentukan efektivitas pakan yang diberikan (Mukti 2012), semakin rendah nilai rasio konversi pakan yang didapat maka semakin baik pakan dimanfaatkan oleh ikan (Muir 1998). Rasio konversi pakan ikan patin selama pemelihaan dengan campuran simplisia kipahit dosis A $(2,13), \mathrm{B}(2,04), \mathrm{C}(1,95)$, dan $\mathrm{D}(1,91)$ tidak berbeda nyata $(\mathrm{P}>0,05)$ dengan kontrol (2,2). Rasio konversi pakan yang relatif sama antara setiap dosis perlakuan dengan kontrol mengindikasikan bahwa pakan yang diberikan pada setiap perlakuan memiliki kualitas yang cukup baik, hal ini merujuk pada Azwar et al. (2010) yang menyatakan bahwa rasio konversi pakan ikan patin berkisar antara 1,93 sampai dengan 2,67.

Menurut Effendie (2002) terdapat dua faktor utama yang mempengaruhi pertumbuhan ikan, yaitu faktor internal dan faktor eksternal. Faktor internal mencakup beberapa aspek diantaranya adalah keadaan genetis, jenis kelamin, umur, parasit dan penyakit, sedangkan faktor eksternal terdiri dari pakan dan suhu perairan. Hasil penelitian ini mendapatkan hasil laju pertumbuhan spesifik ikan patin selama masa pemeliharaan yaitu dosis A (2,73\%), B (2,79\%), C (2,79\%), dan $\mathrm{D}(2,78 \%)$ tidak berbeda nyata $(\mathrm{P}>0,05)$ dengan kontrol $(2,62 \%)$. Kisaran nilai laju pertumbuhan spesifik setiap perlakuan yang tidak berbeda jauh dengan kontrol menunjukkan bahwa pemberian simplisia kipahit dalam pakan sebagai salah satu faktor penentu pertumbuhan berperan cukup baik. Pakan dengan campuran simplisia kipahit dapat dicerna oleh ikan sehingga mampu menunjang pertumbuhan ikan (Sartika 2011) 
dan mempengaruhi laju pertumbuhan spesifik ikan patin.

\section{KESIMPULAN DAN SARAN \\ Kesimpulan}

Berdasarkan penelitian yang telah dilakukan dapat disimpulkan bahwa dosis terbaik perlakuan penambahan simplisia kipahit pada pakan untuk mencegah penyakit MAS pada ikan patin adalah 16,67\%. Dosis tersebut menunjukkan efek imunostimulan terbaik, akan tetapi kipahit tidak memiliki kemampuan bekterisidal. Dosis tertinggi pemberian simplisia kipahit $(16,67 \%)$ aman terhadap fungsi hati sehingga efektif untuk digunakan sebagai pencegah Motile Aeromonas Septicemia (MAS) pada ikan patin.

\section{Saran}

Untuk penelitian selanjutnya disarankan untuk melakukan ekstraksi terlebih dahulu pada tanaman kipahit serta meningkatkan palatabilitas (tingkat kesukaan) pada pakan yang diberi kipahit.

\section{DAFTAR PUSTAKA}

Ambrosio SA, Oki Y, Heleno VCG, Chaves JS, Nascimento PGBD, Lichston JE, Constantino MG, Varanda EM, Da Costa FB. 2008. Constituents of Glandular Trichomes of Tithonia diversifolia : Relationships to Herbivory and Antifeedant Activity. Phytochemistry 69 : 2052-2060.

Azwar ZI, Irma M, Titin K. 2010. Pemanfaatan Ampas Tahu Sebagai Substitusi Tepung Kedelai dalam Formulasi Pakan Ikan Patin. Prosiding Forum Inovasi Teknologi Akuakultur. Jakarta

Citarasu T. 2010. Herbal biomedicines : A new opportunity for aquaculture industry. Aquaculture Int. 18 : 403-414.

Direkbusarakom S, Ezura Y, Yoshimizu M, Herunsalee A. 1998. Efficacy of Thai traditional herb extract againts fish and shrimp pathogenic bacteria. Fish Pathology 33:437-441.
Effendie MI. 2002. Metode Biologi Perikanan. Jakarta : Gramedia Pustaka Utama.

John-Dewole OO, Oni SO. 2013. Phytochemical and Antimicrobial Studies of Extracts from the Leaves of Tithonia diversifolia for Pharmaceutical Importance. Journal of Pharmacy and Biological Sciences. 6:21-25.

Muir JF. 1998. Management for Freshwater Fish Culture, Fish Stocks, and Farm Management. United Nations : Food and Agriculture Organizations.

Mukti RC. 2012. Penggunaan Tepung Kepala Udang Sebagai Bahan Substitusi Tepung Kepala Ikan dalam Formulasi Pakan Ikan Patin (Pangasionodon hypophthalmus). [Skripsi]. Departemen Budidaya Perairan, FPIK IPB. Bogor.

Noegroho A. 2014. Perdagangan Perikanan Nonkonsumsi Capai 1,7 Triliun. kkp.go.id. [3 Mei 2014].

Odayemi AT, Agidigbi TS, Adefemi SO, Fasuan SO. 2014. Antibacterial Activities of Crude Extracts of Tithonia diversifolia Against Common Environmental Pathogenic Bacteria. The Experiment 20(4):1421-1426.

Sakti I. 2013. KKP Targetkan Produksi Patin 1,1 Juta Ton. kkp.goid.[8 Januari 2014].

Sartika Y. 2011. Efetivitas Fitofarmaka dalam Pakan untuk Mencegah Infeksi Bakteri Aeromonas hydrophila pada Ikan Lele Dumbo (Clarias sp.). [Skripsi]. Bogor: IPB.

Saurabh S, Sahoo PK. 2008. Lysozyme : an important defence molecule of fish innate immune system. Aquaculture Research 39, 223-239.

Suherman A. 2013. Daun Kipahit (Tithonia diversifolia) Sebagai Sumber Antibakteri dan Antioksidan. [Skripsi]. Bogor: IPB. 
Wagner H. 1984. Imunostimulants of Fungi and Higher Plants pada Natural Products and Drugs Development, Alfred Benson Symposium 20, Krogsgaard-Larsen P, Christensen S B, dan Kofod H. Eds.Munksgaard, Copenhagen halaman 391.

Wahjuningrum D, Ashry N, Nuryati S. 2008. Pemanfaatan Ekstrak Daun Ketapang
Terminalia cattapa untuk Pencegahan dan Pengobatan Ikan Patin yang Terinfeksi Aeromonas hydrophila. Jurnal Akuakultur Indonesia 7:79-94.

Widyastuti HSC. 2012. Skrining Herbal untuk Streptococcis dan Motile Aeromonad Septicemia (MAS) secara in vitro. [Skripsi]. Bogor: IPB. 